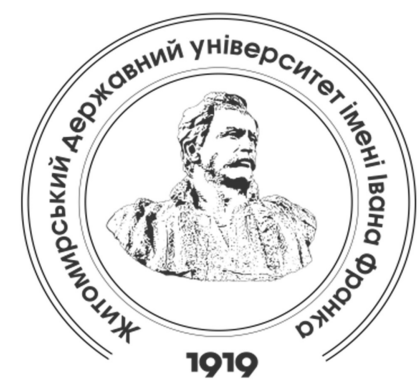

Zhytomyr Ivan Franko State University Journal. Philosophical Sciences. Vol. 2(88)

Вісник Житомирського державного університету імені Івана Франка. Філософські науки. Вип. 2(88)

ISSN: $2663-7650$

\title{
UDC 316:159:168.522
}

DOI 10.35433/Philosophical Sciences.2(88).2020.102-112

\section{COMPETITABILITY OF A PERSONALITY IN THE "POST" ERA}

\section{V. Ohorodniychuk*}

Goal. Carrying out a theoretical and methodological analysis of the competitiveness of the individual in the "Post" era, which is a complex socio-cultural process; unlocking the praxeological potential of the individual for both self-growthand society as a whole. Method. During the research such methods as analysis, synthesis, dialectical, systemic, structural and functional were used. A synergistic methodological approach to competitiveness as a complex and open system was applied. The theoretical basis of the study is the views of such foreign researchers as I. Adizes, F. Fukuyama, K. Hales, and native ones such as V. Voronkova, O. Kyvliuk, V. Min, $V$. Kutyrov. Results. The author argues that at the present stage of the world development, competitiveness should not be simplified to adaptation or conformation. Indeed, the accelerated dynamics of change entails both new threats that mankind has not yet encountered in history, as well as new prospects for development, the power of which has not been realized yet. Such new conditions of competitive prospect are the processes of technologicalization and informatization. Scientific novelty. An attempt was made to consider the main factors of formation of competitiveness of the individual in the Post era. It is determined that the main factor in this process is the interaction of man and technology. During the study it was proved that no machine is capable of replacing humans. Such signs of competitiveness of the individual as intellectual potential, creativity and ingenuity are the key to victory in competition, and technology is a means that is able to optimize human life. Attention is drawn to the fact that competitiveness at the present stage of development of societies is formed at two levels - global and local. It is substantiated that the individual alone is not able to curb the changes that are taking place in the modern world, so it is necessary to create such relationships on the basis of organizational culture, which provide an adequate level of its self-growth and the development of society as a whole.

Keywords: personality, competitiveness, competitive personality, Post era, technology, informatization, organizational culture.

${ }^{*}$ Candidate of Philosophy

(Zhytomyr Ivan Franko State University, Zhytomyr, Ukraine)

N-Marika@ukr.net

ORCID: 0000-0002-9050-8523 


\section{КОНКУРЕНТОСПОРОМОЖНІСТЬ ОСОБИСТОСТI В ЕПОХУ "ПОСТ"}

\section{М. В. Огороднійчук}

мета. Здійснення теоретико-методологічного аналізу конкурентоспроможності особистості в епосі "пост", шо постає складним соиіокультурним проиесом; розкриття праксеологічного потениіалу особистості як для власного зростання, так $i$ суспільства в иілому. Методика. Під час дослідження використовувалися такі методи, як аналіз, синтез, діалектичний, системний, структурно-функиіональний. Застосовувався також синергетичний методологічний підхід до конкурентоспроможності як складної $і$ відкритої системи. Теоретичною основою дослідження є погляди таких зарубіжних дослідників, як: I. Адізес, Ф. Фукуяма, К. Хейлз, так i вітчизняних В. Воронкова, О. Кивлюк, В. Ільїн, В. Кутирьов. Результати. Авторка доводить, ио на сучасному етапі розвитку світу конкурентоспроможність не варто спрошувати $i$ зводити переважно до адаптаиї чи пристосування. Дійсно прискорена динаміка змін таїть у собі як нові загрози, з якими людство у своїй історії ше не стикалось, так $і$ нові перспективи розвитку, потужності яких ше не збагненні. Такими новими умовами конкурентної перспективи постають проиеси технологізаиї та інформатизаиіі. наукова новизна. Здійснена спроба розглянути основні чинники фрормування конкурентоспроможності особистості в епоху "пост". Визначено, ио основним чинником в иьому проиесі виступає взаємодія людини $i$ техніки. В проиесі дослідження доведено, шо жодна машина не здатна замінити людину. Такі ознаки конкурентоспроможності особистості як інтелектуальний потениіал, креативність та винахідливість виступають запорукою перемоги у конкурентній боротьбі, а техніка засобом, який здатен оптимізувати життя людини. Акиентовано увагу на тому, шо конкурентоспроможність, на сучасному етапі розвитку суспільств, формується на двох рівнях - глобальному та локальному. Обтрунтовано, шо особистість самотужки не здатна приборкати ті зміни, які відбуваються в сучасному світі, тому вона з необхіністю створює на основі організаиійної культури такі відносини, які забезпечують відповідний рівень ї̈ самозростання, так і розвиток суспільства в иілому.

Ключові слова: особистість, конкурентоспроможність, конкурентоспроможна особистість, епоха "пост", технологізаиія, інформатизаиія, організаиійна культура.

Problem statement. The whole
contemporary world and each
personality in particular are surviving a
period of considerable changes and
transformations. This is determined by
not only economic, political and social
shifts, but also by the challenges
threatening the people's lives, by the
Covid 19 pandemic, for instance, and
also by another rapidly approaching
world economic crisis which requires
adequate responses of the whole world
community.
It is quite logical that today a
discussion is actively conducted both
on the global and the local levels, as to
the optimization of the society's and of
each individual's live. A contemporary
personality found oneself in the
epicenter of many events, even
challenges, which produce a particular
impact on his/her development.

For instance, in the conditions of the quarantine of early 2020, when the whole world community lives and works under the online regime, a technically unaware person turns out to be an outsider. Such a person has a limited circle of communication; he/she has no adequate links with the surrounding world. Today the social-philosophical understanding of a personality is especially relevant, specifically, of such personal feature as competitiveness. The problem of a competitive personality formation acquires a special importance, as only with such a formulation of the question, it is possible to find and denote the most optimal ways both for the survival of the mankind in general, and specifically for each person.

Degree of scientific development. To characterize the today's stage of the 
development of our civilization, the prefix "post-'is rather frequently used. It is filled with such meanings as 'posthistory', 'postculture', 'postperson', 'postmankind', 'posteconomy, 'postpolocy', etc. The majority of researchers, specifically V. Illyin [7], V. Kutyryov [8], state, that the defining feature of modern society is the anthropological crisis, which radically changes the way of existence and development of a human being. Most humanistic value systems, in their opinion, are transformed into more technological ones, which leads to the emergence of a new type of a human being - a posthuman.

American scholar F. Fukuyama in his work "Out posthuman future" also presents rather a skeptical consideration of the onset of transhumanism as one of the currents that defines modern society [12]. This tendency, in his opinion, is dangerous and even threatening for the further development of the mankind. F. Fukuyama claims that the interference of technology in people's lives is likely to dehumanize a human being himself. According to K. Hales, in the conditions of combination of a person and technology, a posthuman appears; as a result, the society enters a new phase of its development - a socio-technical one.

"In the posthuman, there are no significant differences or absolute distinctions between bodily existence and computer simulation, between the cybernetic mechanism and the biological organism, the teleology of robots, and human goals" [14: 22]. Ukrainian researchers V. Voronkova and O. Kyvliuk note that the use of technology as a resource that easies out human life, arranges the world around it, signalizes the emergence of smart culture [5]. Thus, the development of modern society is conditioned by technological and informational progress, which, in our opinion, provides new competitive advantages for humans.

Outline of the unresolved issues raised in the article. Taking into account these concepts, we can also state that the present, alongside with the threats, at the same time opens up for a person the limitless possibilities of his/her self-realization.This, in its turn, is enabled by a new wave of STR - the information technological one, which is accompanied by the digitalization of society. Therefore, the aim of the article is a socio-philosophical analysis of the competitiveness of the individual in the "post" era, which is a complex sociocultural process, the revealing of the praxeological potential of the individual both for his/her own growth and the society as a whole.

Discussion and results. Prior to the "post" era, a person was seen as a unique creation of nature and oneself, he/she had clearly defined life guidelines and values that guided his/her actions in the appropriate direction, which in most cases was progressive. A person was creating culture, art, his/her personality and individualty, etc. However, the present period puts before the person new requirements and new ways of his/her self-realization. It is worth acknowledging the fact that a modern person cannot imagine himself/herself outside and without information and communication technologies. They became an important condition in the process of his/her further development. Their introduction has significantly changed the place of a person in the modern world, namely: values, his/her moral integrity and individual stability, his/her world perception and worldview. A person is 'commited to' the information-signal environment, which, in its turn, changes the attitude to him/herself, other communicators, to the world as a whole. According to modern researcher E. Levchenyuk, "Internet communication and active 
virtual life change the nature and behavior of communicators. Therefore, under such conditions, such factors that influence the change of identity, the development of the information society and the formation of information culture aquire fundamental importance" [9: 157].

The very life of a modern person, his/her development is determined by change. As the famous and successful writer, entrepreneur I. Adizes notes, life is defined by the following triad: "change - problems - solutions". "Changes are happening faster and faster, and everything around us is intertwined in interdependences" [2: 29]. In fact, this applies to the life both of an individual and of the society as a whole. A contemporary person develops in close cooperation with technique and technologies, which should not be considered only as a threat to the further development of culture, spirituality, etc., but, first and foremost, as a means to be used in the modern world. In this context, the present is characterized by the development of smart-culture, i.e. the use of modern technologies in all spheres of human life. "For now, the information space is filled with elements of various cultures and, as a consequence, has unlimited opportunities to influence people, their place in the virtual environment and, accordingly, is able to transform the axiological systems of a personality" [9: 157]. That is, the content of the information space is characterized by the presence of a network culture, which is the result of interaction of many different people. Thus, of course, under the influence of the culture of the information space, a person's attitude to the world and to other people changes, there happens a reassessment of values, ethical norms, which transforms a person's lifeworld. And such changes can be recorded by a person's acquisition of a new identity the electronic one.

Electronic identity, according to the German researcher M. Fassler, is formed in new conditions of communication, in which a person acquires special competitive features in modern society, in particular, such features as mobility and openness, which directly depends on the number of possible communications, as well as on their content. The well-known Russian researcher, neurolinguist T. Chernihivska in her lecture "How the Internet has changed our brain" notes that "... modern technologies and life in the virtual world have significantly changed the ways information is processed. The process of reading has ceased to be purely linear, information has become easily and quickly accessible, but it has become unreliable. Education in both schools and universities is changing its structure"

[https:/ /infosila.ee/main/2207neyrolingvist-tatyana-chernigovskayakak-internet-vliyaet-na-nashmozg.html].

Both constructive and destructive changes can be traced in the impact of technology on human life. But the important question in this is whether a modern person is able to abandon them. We think the answer will be negative. As V. Bychkov remarks, and it is difficult to disagree with this, "... like it or not, but the future of art is in the virtual world of network spaces" [4: 139].

This year, when the humanity has switched to Online life, access to almost all the world's major museums is free to visit at any time of day, such as the virtual doors open to the Louvre, the Van Gogh Museum in the Netherlands, the Dali Theater Museum, the British Museum, the Galileo Museum, the National Gallery of Art (USA). In Ukraine, there are also many virtual tours of museums, churches, palaces, 
in particular, a visit to the Church of the Holy Spirit in Rohatyn, Dnipropetrovsk National Historical Museum named after D. Yavornytsky and the palace of Cyril Rozumovsky in Baturyn; you can walk along the corridors of Ostroh Castle, and much more can be seen without our leaving home, thanks to modern information and communication technologies.

Thus, in this aspect, a modern person must not only adapt to fleeting changes, but also subordinate them to him/herself. It is worth remembering that technology should not replace a human being, it is, above all, a means created by people to optimize their vital functions in the new digital age. An example of this is the organization of educational process in Ukraine, which is related to quarantine measures.

Although the current stage of technology development has allowed the world to be open to communication, interaction, but physically we found ourselves in a limited space. Thanks to information and communication technologies, work and studies can continue without breaks. And the person, who has mastered the logic of organizing his/her life in the new conditions, is competitive.

It is quite reasonable to state that the beginning of the XXI century is characterized by a new stage of competition in all spheres of human life. Significant changes in economic, political, socio-cultural conditions are taking place, which necessarily motivate the individual to comprehensive development, to the formation of such a quality of her/his own existence as competitiveness.

This accelerated dynamics requires from the modern personality such qualities as social responsibility, mobile response to external changes, which, in turn, affirm in the individual independence and efficiency in decision-making, willingness to communicate in a competitive environment, the ability to responsively adapt to new conditions and situations, the ability to take risks, etc. These are personal traits which characterize this individual as a competitive one in the modern world. But it should be noted that today the individual, forming such a level of development as competitiveness, can not be a kind of a 'lone wolf'. He/she must necessarily either create his/her own team or be a part of it. According to Ukrainian researchers in the field of forming a new management paradigm, namely $F$. Vlasenko, E. Levchenyuk, D. Tovmash, "... absolute perfection does not exist, so it has a rational and realistic alternative - to create a complementary team. The starting point in this strategy is that the leader as a manager cannot be perfect and ideal, so, realizing this, it is necessary to move from tasks that have no solutions to a completely different level both within the organization and in management schools" [15: 36].

As can be seen from the above, the authors quite successfully use the ideas of the already mentioned I. Adizes. At least one, namely the idea expressed in the work "The ideal leader. Why can't we become one and what results from it?", in which the author points out that ideal people, including leaders, do not exist and cannot exist at all. Therefore, at the present stage of development a person can be qualified as a competitive one if he/she is able to work in a team and at the same time, this person contributes both to his/her own development and formation, and to the team (group, society) as a whole [1].

It is believed that competitiveness can be described as the ability and dynamics of adaptation to changing conditions. "Management of the competitiveness of the enterprise, the efficiency of which should be ensured both under the influence of improving the organization of production, labor and management, and the ability to 
adapt to contemporary business conditions" [3: 133]. But competitiveness, in our opinion, is not just adaptation. Indeed, if we reduce competitiveness only to adaptation, then quite logically the question arises about the innovativeness of both the individual and the team as a whole, which is the source of changes, which become a competitive advantage that brings to a new level of development a personality, as well as a team, an organization, society, etc. "The competitiveness of a person as the main factor of activity is determined by his/her ability to withstand negative circumstances and lead change by increasing his/her competencies and, owing to active intelligence, to ensure the innovative development of the enterprise" [6: 135].

Therefore, to be competitive, a person must always be ready for change, use the acquired knowledge and competencies. "If a person as an employee of the enterprise does not meet modern requirements as to education, skills, culture, innovation, initiative, the company cannot join the ranks of innovative and intellectually oriented market participants" [6: 135]. In fact, this confirms our view that the modern individual is able to realize his/her potential only in terms of creating a complementary team which can introduce a competitive reserve and thus make a breakthrough in a particular area of activity that will ensure his/her success, recognition, enrichment and more.

Competitiveness of an individual, according to many researchers, is realized due to such factors as "intellectualization of society, socialization of labor, psychological adaptability to change, increase of innovation in all spheres of life" [6: 135]. We can fully agree with the above list of competitive factors that are necessary at the present stage of development of societies. But, in our opinion, the development of information technology is also worth adding, which accelerates and can change the structure and activity direction of the industry, enterprise and so on. Besides, no less important factor of competitive advantage is the organizational culture, which is the basis for the development of the enterprise or the organization. Thus, G. Zakharchyn and O. Yurynets rightly note that "... today at the level of individual competitiveness, and eventually, of the competitiveness of the enterprise, an important factor is the organizational culture that strengthens the sense of economic freedom, because in the scale of values freedom takes quite a special place in the modern world"[6: 135].

So, emphasizing the creation of a team as a subject of activity, we state the fact that the people who are part of this team are various: they are from various cultures, profess different religions, consequently, they have various values, which essentially influences the organization of their activities. Therefore, to create a competitive team, the manager must take into account these features in the selection of employees. Therefore, in view of this, it is necessary to involve anthropologists who would provide clear guidance on the characteristics of a particular employee, pointing out his/her advantages and disadvantages. After all, the role of culture and religion in the organization of activities has long been proven, and, therefore, they can be used as competitive advantages.

For a long time, resources have been recognized as the main factor of competitive advantage in production. But, as we know, resources are exhaustive, especially natural ones, such as oil, gas, coal, etc., and as it turned out, they do not have a longterm perspective. This is an indisputable fact.

The fact is indisputable indeed, but today, in connection with the global 
pandemic, we are observing slightly different trends, as consumption has declined, particularly in oil products. Therefore, the raw material resource has lost its competitive advantage for other reasons that the world has not yet encountered. The price on oil, which was recorded on April 20, 2020, became negative for the first time. On that day, the price of WTI oil, with delivery in May, on the New York Mercantile Exchange was equal to "0" dollars per barrel and later it "slumped" to minus 37 dollars per barrel. This is due to the fact that oil companies have accumulated a surplus that they have nowhere to store. This event will go down in world history. Thus, resources as a competitive advantage become a thing of the past [https://zaxid.net/tsina_nafti_marki_wt i_vpershe_v_istoriyi_stala_vidyemnoyu_ n1501158]. Today, new factors of competition come to the fore. Among them are the processes of technologicalization, informatization and intellectualization of all spheres of social activity. "...Intellectual competitiveness, which partially absorbed the essential characteristics of such concepts as "financial competitiveness", "innovative competitiveness", competitiveness", "social competitiveness - competitiveness of human capital" [11:22].

Thus, the determining factor in competition is human capital, and the main competitive advantage of organizations and enterprises is organizational culture. In modern philosophical literature there are many definitions of organizational culture. For example, G. Morgan notes that the culture of the organization directly reflects its essence and, at the same time, provides the conditions for a coherent perception of reality. "Organizational culture is such an effective phenomenon through which people together create and renew the world" [10: 162]. Other researchers, in particular, such as S. Gaiduchenko, M. Novikova, O. Kharchyshyna, argue that organizational culture is only an attribute of the organization, which can be exposed to various external influences; organizational culture is a product of the experience of social groups, due to which the company can function effectively [13: 148-151]. Organizational culture as a competitive advantage, in our opinion, appears primarily as a way to form relationships and interactions between employees within the collective body. That is, the collective body becomes a kind of homogeneous organism, in the presence of heterogeneous elements, that act in harmony to achieve a common goal. In other words, organizational culture is a tool that ensures the viability of the company, determining the system of its priorities, taking into account the values and norms of behavior of all members of the company, which will contribute to its effective activity.

Competitiveness of the individual and the enterprise or the company have a dialectical nature of existence due to such a factor as organizational culture. On the one hand, at the personal level, organizational culture promotes the development of professional growth of a particular employee, while necessarily stimulating the satisfaction of the employee's desire for professional selfgrowth, creativity manifestation and activity. Thus, according to $\mathrm{V}$. Voronkova and O. Kivlyuk, "professional growth presupposes the creation of favorable conditions for selfimprovement and self-realization, for changing the type of activity, improving communication processes, mastering new knowledge and gaining new experience. As the level of competence increases, the level of labor potential grows too, as well as, consequently, the possibility of using its intellectual component as a competitive advantage" 
[5: 136]. And, on the other hand, the growth of personal potential enables the competitiveness of the enterprise. That is, only at the expense of human capital with the corresponding qualitative signs the competitiveness of the whole collective body is possible. For example, such signs of individual competitiveness as knowledge, the appropriate level of intellectual development are transformed at the enterprise level into the intellectual potential of the enterprise; the appropriate level of development of the employee's own culture and values at the enterprise level turns into the functioning of organizational culture and value system at the enterprise; professional competence and creativity at the collective level are transformed into an intellectual resource and innovative activity, which, in turn, will ensure the efficiency of the company's or enterprise's activity. V. Voronkova rightly notes that "professional competence is the result of a collective learning process, so at the enterprise level it is considered as a collective competence and belongs to those components of human competitiveness that form the intellectual resource of the enterprise and its future competitiveness" [5: 137]. V. Voronkova rightly notes that "professional competence is the result of a collective learning process, so at the enterprise level it is considered as a collective competence and belongs to those components of human competitiveness that form the intellectual resource of the enterprise and its future competitiveness" [5: 137].

So, human capital with its creativity, ingenuity, creative potential of an individual are the necessary main competitive advantages for enterprises. And it is owing to the organizational culture that a person's system of values at the enterprise level are transformed into a system of values that are professed by all members of the team working at the enterprise. Therefore, organizational culture is a form of collective cognition that simultaneously performs several functions, in particular, it is the expansion of the competitive space, enabling each of the market participants to find their special place, and perhaps most importantly, the balanceness of the competitive space.

Thus, a modern person and all forms of his/her collective coexistence (social groups, society, world community) are and develop under the pressure of many challenges that humanity as a whole has not yet faced in its history. But they simultaneously act as new conditions for personal development. At the same time, the signs of individual competitiveness, which we outlined above, in the new digital age, necessarily make this individual stable and ready for any changes and challenges. This becomes a special value both for the person and for enterprises, organizations, turning into organizational adaptability.

These competitive advantages in today's conditions are formed on two levels simultaneously - global and local ones.

At the global level, competitive advantages are due to the processes of technologicalization and informatization of all spheres of the society's activity; at the local level, these are the features of their implementation and use in accordance with the culture, traditions and values of this or that society. Accordingly, the interaction of the global and the local causes the emergence of new sources of competitive advantage, which have an intangible nature.

For instance, talent, organizational culture, innovative creative ideas, professional competencies, which once again confirm our view that the basis of competitiveness at the present stage of development of our civilization is human capital, based on intelligence, 
knowledge, innovation capacity, ability to work creatively, which no progressive machine can replace. A person must constantly improve his/her abilities, which will ensure his/her development and resistance to any changes and transformations.

Conclusions and directions for future research. The changes that characterize the beginning of the XXI century are taking place in all spheres of social life. The challenges produced by these changes motivate both the individual and the society as a whole to further progressive development, to forming such a property of their existence as competitiveness. The development of the latter is due to many factors, namely: to the level of technologicalization and informatization of society, without which the modern society does not imagine its existence, because they are both catalysts for these changes. Competition as such and success in competition directly depend on changes, on the ability of an individual not only to adapt and adjust oneself, but also, using his/her intellectual potential, creativity and ingenuity, to become a determining factor in these changes. But the individual is not able to tame the wind of change' all alone, for this it is necessary to create on the basis of organizational culture such production relations that shape the competitiveness of the corporation, the company, which will allow the development of both the individual and the society as a whole.

\section{LITERATURE}

1. Адизес И. Идеальный руководитель. Почему им нельзя стать и что из этого следует. М.: ААЬПИНА ПАБАИШЕР, 2014. 360с.

2. Адізес I. Управління змінами дмя досягнення найліпшого результату в бізнесі і повсякденному житті / пер.з англ. Т.Семигіної. K, Форс Україна, 2018. 400 с.
3. Артеменко $\Lambda$. П., Піддубна А. С. Організаційно-економічний механізм управління конкурентоспроможністю промислового підприємства. Економічний вісник Національного технічного університету України. 2015. № 12.

4. Бычков В. В. Триалог: Разговор Второй о философии искусства в разных измерениях. М.: ИФРАН, 2009. 212 c.

5. Воронкова В. Аюдина у освітньому просторі smartсуспільства. Міждисциплінарні дослідження складних систем: зб. наук. праць. Київ: Вид-во НПУ імені М. П. Драгоманова. 2017. № 10-11. С. 88-95.

6. Захарчин Г. М. Системний підхід до конкурентоспроможності. Вісник Національного університету "Аьвівська політехніка". 2011. № 720: Менеджмент та підприємництво в Україні: етапи становлення і проблеми розвитку. С. 133-138.

7. Іиьїн В. Епоха "пост": Аюдина в перспективі "нової духовності". Філософсько-світоглядні засади буття мюдини. № 5. 2010. С. 43-49.

8. Кутырёв В. А. Разум против человека (Философия выживания в эпоху постмодернизма). МоскваБерлин: Директ-Медиа, 2015. 102 с.

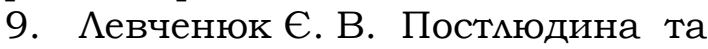
постиюдство: особливості прояву. Гуманітарний вісник Запорізької державної інженерної академії. 2015. № 60. С. 152-161.

10. Морган Г. Имиджи организации: восемь модемей организационного развития / пер. с англ. под. ред. Н. Капиной. М.: Вершина, 2006. 416 с.

11. Тарнавська $\mathrm{H}$. конкурентних переваг в умовах експансії нововведень. Економіка України. 2011. С.16-27.

12. Фукуяма $\Phi$. постчеловеческое будущее: Последствия биотехнологической ревоцюции / пер. с англ. М.Б. Аевина. 
М.: ООО "Издатецьство АСТ": ОАО "АЮКС". 2004. 349 c.

13. Харчишина О. В. Дослідження сутності категорії "організаційна культура". Вісник ЖДТУ. № 2 (56). 2011. C.148-151.

14. Хейлз K. Як ми стали постАюдством. Віртуальні тіла в кібернетиці, $\quad$ ітературі та інформатиці / переклад Є. Марічева. К.: Ніка-Центр, 2013. 426 с.

15. Vlasenko F., Levcheniuk Ye, Tovmash D. Conceptual fundamentals of contemporary management paradigm: theoretical and methodological analysis. Interdisciplinary Studies of Complex Systems. No. 15 (2019). P. 34-46.

\section{REFERENCES (TRANSLATED \& TRANSLITERATED)}

1. Adizes, I. (2014). Ideal'nyj rukovoditel'. Pochemu im nel'zja stat' $i$ chto iz jetogo sleduet [The ideal leader. Why it is impossible to become one and what follows from this]. M.: AL"PINA PABLIShER (in Russian).

2. Adizes, I. (2018). Upravlinnja zminamy dlja dosjagnennja najlipshogo rezul'tatu $v$ biznesi $i$ povsjakdennomu zhytti [Change management to achieve the best results in business and daily life]. K.: Fors Ukrai'na (in Ukrainian).

3. Artemenko, L. P., Piddubna, A. S. (2015). Organizacijno-ekonomichnyj mehanizm upravlinnja konkurentospromozhnistju promyslovogo pidpryjemstva [Organizational and economic mechanism for managing the competitiveness of an industrial enterprise]. Ekonomichnyj visnyk Nacional'nogo tehnichnogo universytetu Ukrai'ny, 12 (in Ukrainian).

4. Bichkov, V. (2019). Tryalog: Razgovor Vtoroj o fylosofyy yskusstva $v$ raznih yzmerenyjah [Trialogue: Conversation Two on the Philosophy of Art in Different Dimensions]. M.: YFRAN (in Russian).

5. Voronkova, V. (2017). Ljudyna u osvitn'omu prostori smart-suspil'stva
[Man in the educational space of smartsociety]. Mizhdyscyplinarni doslidzhennja skladnyh system : $z b$. nauk. prac'. Kyi'v: Vyd-vo NPU imeni $M$. P. Dragomanova, 10-11, 88-95 (in Ukrainian).

6. Zaharchyn, G. (2011). Systemnyj pidhid do konkurentospromozhnosti [System approach to competitiveness]. Visnyk Nacional'nogo universytetu "L'vivs'ka politehnika", 720: Menedzhment ta pidpryjemnyctvo $v$ Ukrai'ni: etapy stanovlennja i problemy rozvytku, 133-138 (in Ukrainian).

7. Il'i'n, V. (2010). Epoha "post": ljudyna $\mathrm{v}$ perspektyvi "novoi' duhovnosti" [The era of "post": man in the perspective of "new spirituality"]. Filosofs'ko-svitogljadni zasady buttja ljudyny, 5, 43-49 (in Ukrainian).

8. Kutyrjov, V. (2015). Razum protiv cheloveka (Filosofija vyzhivanija $v$ jepohu postmodernizma) [Mind versus Man (Philosophy of Survival in the Postmodern Era)]. Moskva-Berlin: Direkt-Media (in Russian).

9. Levchenjuk, Je. (2015). Potljudyna ta postljudstvo: osoblyvosti projavu [Posthuman and posthuman: features of manifestation]. Gumanitarnyj visnyk Zaporiz'koi' derzhavnoi' inzhenernoi' akademii', 60, 152-161 (in Ukrainian).

10. Morgan, G. (2006). Imidzhi organizacii: vosem' modelej organizacionnogo razvitija [Organizational Images: Eight Models of Organizational Development]. M.: Vershina (in Russian).

11. Tarnavs'ka, N. (2011). Rozvytok konkurentnyh perevag $\mathrm{v}$ umovah ekspansii' novovveden' [Development of competitive advantages in the conditions of expansion of innovations]. Ekonomika Ukrai'ny, 16-27 (in Ukrainian).

12. Fukujama, F. (2004). Nashe postchelovecheskoe budushhee: Posledstvija biotehnologicheskoj revoljucii [Our Posthuman Future: The Consequences of the Biotechnology 
Revolution]. M.: OOO "Izdatel'stvo AST": OAO "LJuKS" (in Russian).

13. Harchyshyna, O.

(2011).

Doslidzhennja sutnosti kategorii' "organizacijna kul'tura" [Research of the essence of the category "organizational culture"]. Visnyk ZhDTU, 2 (56), 148-151 (in Ukrainian).

14. Hejlz, K. (2013). Jak my staly postljudstvom. Virtual'ni tila $v$ kibernetyci, literaturi ta informatyci
[How we became posthuman. Virtual bodies in cybernetics, literature and computer science]. K.: Nika-Centr (in Ukrainian).

15. Vlasenko, F., Levcheniuk, Ye, Tovmash, D. (2019). Conceptual fundamentals of contemporary management paradigm: theoretical and methodological analysis. Interdisciplinary Studies of Complex Systems, 15, 34-46 (in English).

Receive: October 12, 2020 Accepted: November 16, 2020 